\title{
Complexity Science and Educational Research Conference - Shanghai 2010: Prologomena
}

WILLIAM E. DOLL, JR.

Louisiana State University (USA)

In November of 2010, the Complexity Science and Educational Research consortium- a group of complexivists founded in Canada in 2003 and holding meetings at various international sites on an as is basis -- accepted an invitation from East China Normal University to hold a meeting in Shanghai, China where it combined with Chinese scholars, students teachers, and administrators interested in Complexity, Chinese Culture, and Curriculum Reform. Over 300 educators, mostly from China, were treated to keynote talks by some of the leading complexity educators in the world; in turn western complexity educators came in direct contact with both Chinese culture and some of its more innovative school reform movements. The conference was full of dynamic interplay. The visiting of schools experimenting in the Chinese curriculum reform movement, added another dimension to this interplay. The East-West bridge between these two cultures - "a bridge that is not a bridge," to borrow a term Jie Yu uses in her comments on the Chinese papers - is reflected in the choice of papers chosen for this issue.

We, Barney Ricca, Jie $\mathrm{Yu}$, and I, wish more papers could be chosen for this special issue of Complicity: An International Journal of Complexity and Education. Time prohibits such, but we are pleased to bring forth three papers from native English speakers, and four from native Chinese speakers. These papers come from quite different perspectives, as readers will note; yet, as Barney says in his Editorial, there is a "beyondness" which bridges these differences. Indeed this beyondness, makes "a difference which is a difference," thereby unifying the western, analytic tradition with an eastern hermeneutic one. History plays a part in both traditions, but differently. In the West, history is allied with progressive time, the present building on the past and leading on to the future. In the East, history is recursive, the stories folding back on themselves in a timeless fashion, asking us to continually reexamine, reflect on who and what we are. The interplay of these two, a dance of the analytic and the hermeneutic, provides for each culture an awakening of the new. From this new another new emerges. We not only learn from our differences, we need our differences, if we are to learn.

This conference is only the beginning of building a mythical bridge that each group may walk and talk with the other. Even as we bring this journal to publication, projects 
are being developed in North America and China for complex, cooperative collaboration. We do live in a post-modern, global, complex world. May you readers be inspired, as we editors are, with the educational, intellectual, social possibilities inherent in such collaborations. We look forward to Complicity, a journal founded by the Complexity Science and Educational Research consortium, publishing more issues where culture and curriculum come into dynamic interplay.

(c) Copyright 2012. The author, William E. Doll, Jr., assigns to the University of Alberta and other educational and non-profit institutions a non-exclusive license to use this document for personal use and in courses of instruction provided that the article is used in full and this copyright statement is reproduced. The authors also grant a non-exclusive license to the University of Alberta to publish this document in full on the World Wide Web, and for the document to be published on mirrors on the World Wide Web. Any other usage is prohibited without the express permission of the authors. 